\title{
THE ASSOCIATION BETWEEN INSULIN-LIKE GROWTH FACTOR-1 AND INSULIN-LIKE GROWTH FACTOR BINDING PROTEIN-3 LEVELS AND CLINICAL PROGNOSIS IN PATIENTS WITH ISCHEMIC STROKE
}

\author{
Hasan YAŞAR, Temel TOMBUL, Aysel MiLANLIOĞLU \\ Yüzüncü Yll University Faculty of Medicine Neurology Department, VAN
}

\begin{abstract}
OBJECTIVE:Recent studies report that the insulin-like growth factor system may be involved in stroke pathogenesis, and is reported to increase myelination, maturation, cell proliferation and neuronal sprouting of the central nervous system.The aim of the present study is to demonstrate the role of insulin-like growth factor system in ischemic stroke pathogenesis and its association with the prognosis by investigating insulin-like growth factor-1 and insulin-like growth factor binding protein-3 levels in patients diagnosed with acute ischemic stroke.

MATERIAL and METHODS: Sixty-eight patients and 20 healthy individuals were included to this study. Clinical evaluation of the patients was performed according to National Institute of Health Stroke Scale and functional outcomes were graded according to Modified Rankin Scale. Bamford classification was used for the clinical classification of ischemic strokes, and the TOAST system for etiological classification. Each patient's levels of insulin-like growth factor-1 and insulin-like growth factor binding protein-3 were measured on the first, fifth and thirtieth day of ischemic stroke.

RESULTS: Only the levels of insulin-like growth factor binding protein-3 on the day of 5 were significantly decreased compared to the control group. The decrease in IGF-1 values was associated with an increased risk of death and was accompanied by clinical worsening and decreased functionality.

CONCLUSION: It has been concluded that the levels of investigating insulin-like growth factor-1 and insulin-like growth factor binding protein-3 may affect mortality risk, clinical condition and functionality outcomes in patients presenting with ischemic stroke, and further studies are needed for the investigation of different effects of insulin-like growth factor1 in future.
\end{abstract}

Key Words: Ischemic stroke, insulin-like Growth Factor,prognosis.

\section{İNSULIN-BENZERI BÜYÜME FAKTÖRÜ-1 VE INSULIN-BENZERI BÜYÜME FAKTÖR BAĞLAYICI PROTEIN-3 SEVIYELERI ILE ISKEMIK INMELI HASTALARIN KLINIK PROGNOZ ILIŞKISI}

ÖZET

AMAÇ: Daha önceki çalışmalarda insulin-benzeri büyüme faktör sisteminin santral sinir sisteminde miyelinizasyon, hücre proliferasyonu, maturasyon ve nöronal filizlenmeye neden olarak inme patogenezinde yer alabileceği rapor edilmiştir. Bu çalışmanın amacı akut iskemik inmeli hastalarda insulin-benzeri büyüme faktörü-1 ve insulin-benzeri büyüme faktör bağlayıcı protein-3 seviyelerinin iskemik inme patogenezindeki rolünü ve prognoz ile ilişkisinin ortaya konulmasıdır. GEREÇ ve YÖNTEM: Sadece 5. gündeki insulin-benzeri büyüme faktörü bağlayıcı protein-3 seviyeleri kontrole göre anlamlı düşüktü ve düşük insulin-benzeri büyüme faktörü-1 düzeyi artmış ölüm riski, kötü klinik durum ve azalmış fonksiyonellik ile ilişkiliydi.

BULGULAR: Sadece 5. gündeki insulin-benzeri büyüme faktörü bağlayıcı protein-3 seviyeleri kontrole göre anlamlı düşüktü ve düşük insulin-benzeri büyüme faktörü-1 düzeyi artmış ölüm riski, kötü klinik durum ve azalmış fonksiyonellik ile ilișkiliydi.

SONUÇ: İnsulin-benzeri büyüme faktörü-1 ve insulin-benzeri büyüme faktör bağlayıcı protein-3 seviyelerinin hastaların mortalite riski, klinik durum ve fonksiyonel sonlanımını etkileyebildiği ve gelecekte insulin-benzeri büyüme faktör sisteminin farklı etkilerinin araştırıldığı bașka çalışmalarada ihtiyaç olduğu sonucuna varıldı.

Anahtar Sözcükler: İskemik inme, insulin-benzeri büyüme faktörü, prognoz.

\footnotetext{
Corresponding author: Aysel Milanlığlu, Asst. Prof. MD. Yüzüncü Yıl University Faculty of Medicine Neurology Department Van, Turkey.

Telephone: +90432 $2167519 \quad$ E-mail: ayselmilanlioglu@yahoo.com

Received: 07.11.2014 Accepted: 19.01.2015

This article should be cited as following: Yasar H, Tombul T, Milanlığlu A. The association between insulin-like growth factor-1 and insulin-like growth factor binding protein-3 levels and clinical prognosis in patients with ischemic stroke. Turkish Journal of Cerebrovascular Diseases 2015 ; 21 (2): $30-35$. doi:10.5505/tbdhd.2015.00000.

This study was presented as poster in 8 th World Stroke Congress, Brazil,
} 


\section{INTRODUCTION}

Cerebrovascular diseases are a group of conditions with a high prevalence among general population commonly lea ding to permanent disability and low quality of life, $85 \%$ of which are related to ischemic events (1).

Growth hormone and insulin-like growth factor-1 system (GH-IGF-1 system) are known to be involved in development of aging and different aging-related diseases like cardiovascular disease, stroke (2), cancer (3) and Parkinson's disease (4).

Insulin-like growth factor 1 is a single-chain polypeptide that shares homology with proinsulin. The IGF system is composed of multiple receptors and ligands. It includes three ligands (IGF-1, IGF-2, and insulin), four receptors, at least six highaffinity binding proteins and binding protein proteases. The bioavailability of IGF1 is regulated by its binding to IGF binding proteins (IGFBPs) (5). Insulin-like growth factor-1 may have a key role in embryonic and postnatal development, in tissue hemostasis such as regulation of cell proliferation, differentiation, an inhibitor of cell apoptosis and necrosis, plasticity and survival of the nervous system (6). This data supported by experimental studies on hypoxic/ischemic brain damage in rats demonstrated that IGF-1 stimulates oligodendrocyte progenitors as well as neuronal proliferation and differentiation, increases myelin expression, modulates brain plasticity, and provides neuroprotective effects via its influence on blood-brain barrier (7-8).

Several epidemiologic studies have reported an inverse relation between low IGF-1 levels and the increased mortality and morbidity of ischemic heart disease and stroke $(9,10,11)$. In fact, a study has shown that low IGF-1 levels increase mortality risk following ischemic and hemorrhagic stroke by 1.5 and 5.2 fold, respectively (12).

In the present study, we investigated IGF-1 and IGFBP-3 levels at the initial 24 hours, on the day of 5 and 30 in patients diagnosed with acute ischemic stroke in order to demonstrate the role of these parameters in ischemic stroke pathogenesis and their association with the prognosis.

\section{MATERIAL AND METHODS}

\section{Patients}

Sixthy-eight patients admitted to the neurology clinic due to acute ischemic stroke and a control group of 20 healthy subjects were included. The design of our study was approved by the hospital ethics committee. Patients were evaluated with various tests at the initial 24 hours, on the day of 5 and 30 following acute cerebral ischemic stroke, and IGF-1 and IGFBP-3 levels were assessed at these time points.

Neurological examination, imaging studies and etiological evaluations were performed for each patient. Bamford clinical classification (13) was used to determine the subgroups of ischemic stroke, and TOAST classification (14) was used for etiological classification.

Clinical evaluation of the patients was performed according to National Institute of Health Stroke Scale (NIHSS) (15) and functional outcomes of ischemic stroke were assessed according to Modified Rankin Scale (MRS) one month later (16).

\section{Biochemical Analysis}

Venous blood samples were taken into biochemistry tubes and stored at $+40 \mathrm{C}$ in the fridge following centrifugation, and studied in the hormone laboratory at the initial 24 hours, on the fifth and thirtieth day. The samples were studied using commercial kits adaptable for the Immulite 2000 device in Immulite 2000 of BIO DPC. Reference range of IGF-1 was detected as 25 $\mathrm{ng} / \mathrm{mL}-1600 \mathrm{ng} / \mathrm{mL}$ while the reference range of IGFBP-3 was $0.5 \mu \mathrm{g} / \mathrm{mL}-1.40 \mu \mathrm{g} / \mathrm{mL}$.

\section{Statistical Analysis}

Statistical analyses of the present study were performed with the SPSS (version 14) statistical program. IGF-1 and IGFBP-3 levels were compared between the patient group and control group using t-test at 24 hours, on the day of 5 and 30, and 95\% confidence interval analyses were performed. The effect of IGF-1 and IGFBP-3 levels on mortality rates on the first and fifth day were assessed with logistic regression analysis. Based on the time points on the first and fifth day, clinical condition and the change in blood parameters were assessed using repetitive t-test. The association between clinical condition and the changes in blood parameters on the first, fifth and thirtieth day were analyzed with Pearson's correlation test. Tukey's multiple comparisons test was used for intergroup comparisons of the values with significant difference. Statistical significance was expressed as $\mathrm{p} \leq 0.05$. 


\section{RESULTS}

The mean age was $60.07 \pm 15.65$ years in the patient group and $56.45 \pm 11.50$ years in the control group. There were 31 females (45.59\%) and 37 males (54.41\%) in the patient group while there were 9 females (45\%) and 11 males (55\%) in the control group. There was no difference between the patient group and the control group regarding age and gender.

Based on Bamford classification, there were 13 patients (19.12\%) in lacunar infarct (LACI) group, 18 patients $(26.47 \%)$ in partial anterior circulation infarct (PACI) group, 20 patients $(29.41 \%)$ in posterior circulation infarct (POCI) group, and 17 patients $(25 \%)$ in total anterior circulation infarct (TACI) group.

Based on the TOAST classification, there were 30 patients $(44.12 \%)$ with large artery atherosclerosis, $16(23.53 \%)$ with cardioembolic infarct, 13 (9.12\%) with lacunar infarct, 6 (8.82\%) with unknown cause, and $1(1.47 \%)$ patient with heterozygous F5 Leiden mutation and 2 (2.94\%) with hyperhomocysteinemia among other identifiable causes.

According to the descriptive statistical data of mortality rates among these patients, exitus occurred during the first 5 days in 4 patients (5.88\%), and after the first 5 days during inpatient treatment in 3 patients (4.41\%). Nine patients (13.24\%) who were discharged from our clinic died within 30 days. Thus, exitus occurred in 16 patients $(23.53 \%)$ within 30 days. The number of patients who survived and attended the control visit on the day of 30 was 27 (39.71\%) while the number of patients who survived but did not/could not attend the visit was 25 (36.76\%).

Comparison of IGF-1 and IGFBP-3 levels at the initial 24 hours, on the day of 5 and 30 showed statistically significant lower levels in the patient group compared to the controls only for the IGFBP-3 levels on the day of 5 . There was no relevant difference between the patient group and the control group regarding IGF-1 and IGFBP-3 levels measured at other time points (Table 1).

The evaluation of the effect of these levels on mortality rates is presented in Table 2 . These findings show that the decrease in IGF-1 values measured on the fifth day in the patient group had a statistically significant significance on mortality rates $(p<0.05)$. The levels of IGF- 1 and IGFBP-3 on the fifth day were significantly lower than those
Table 1. Comparison of IGF-1 and IGFBP-3 levels according to the days in patient and control groups.

\begin{tabular}{lccc}
\hline & Control & Patient & \\
& $\mathrm{M} \pm \mathrm{SD}$ & $\mathrm{M} \pm \mathrm{SD}$ & $\mathrm{t}$ \\
\hline First day IGF-1 & $107,70 \pm 29,29$ & $120,70 \pm 59,06$ & $-0,948$ \\
First day IGFBP-3 & $3,62 \pm 0,86$ & $3,31 \pm 1,14$ & 1,130 \\
Fifth day IGF-1 & $107,70 \pm 29,29$ & $111,18 \pm 56,91$ & $-0,262$ \\
Fifth day IGFBP-3 & $3,62 \pm 0,86$ & $2,84 \pm 1,25$ & $\mathbf{2 , 5 9 8}$ \\
Thirtieth day IGF-1 & $107,70 \pm 29,29$ & $135,42 \pm 59,57$ & $-1,908$ \\
Thirtieth day & $3,62 \pm 0,86$ & $3,78 \pm 1,30$ & $-0,456$ \\
IGFBP-3 & & &
\end{tabular}

Table 2. Evaluation of IGF-1 and IGFBP-3 levels impact on the mortality rates.

\begin{tabular}{|c|c|c|c|c|c|}
\hline & \multicolumn{3}{|c|}{ Standard } & \multicolumn{2}{|r|}{ Hazard } \\
\hline & B & Error & Wald & $\mathbf{P}$ & Ratio \\
\hline $\begin{array}{l}\text { First day } \\
\text { IGF-1 }\end{array}$ & ,008 & ,006 & 1,805 & 179 & 0,992 \\
\hline $\begin{array}{l}\text { First day } \\
\text { IGFBP-3 }\end{array}$ & ,058 & 250 & ,054 & 816 & 1,060 \\
\hline $\begin{array}{l}\text { Fifth day } \\
\text { IGF-1 }\end{array}$ & $\begin{array}{c}- \\
, 017\end{array}$ & , 008 & 4,980 & ,026* & 0,983 \\
\hline $\begin{array}{l}\text { Fifth day } \\
\text { IGFBP-3 }\end{array}$ & $\begin{array}{c}- \\
, 543\end{array}$ & 308 & 3,105 & ,078 & 0,581 \\
\hline
\end{tabular}

measured on the first day. While there was no relevant association between the IGF-1 and IGFBP3 levels on the first and thirtieth day and also NIHSS and MRS scores, significant results were obtained on the day of 5. An association was found between the decrease in IGF-1 and IGFBP- 3 values and the increase in NIHSS scores on the day of 5 $(\mathrm{r}=-0.35$ and $\mathrm{r}=-0.37$ ).

Based on Bamford classification, the analysis of the association between NIHSS and MRS scores and serum IGF-1 and IGFBP-3 levels showed that the patients in TACI group had the highest NIHSS on the first day; however, there was no statistically significant association between IGF-1 and IGFBP-3 levels and ischemic stroke subtypes. There was no significant difference between LACI, PACI and POCI groups regarding IGF-1 and IGFBP-3 levels on the fifth day. The lowest IGF-1 value was seen in the TACI group and the highest IGF-1 level was seen in the PACI group and this finding was also consistent for IGFBP-3 value in the same subgroups.

There was no statistically significant association between the subgroups of TOAST

Turkish Journal of Cerebrovascular Diseases 2015; 21 (1): 30-35 
classification and IGF-1 and, IGFBP-3 levels.

\section{DISCUSSION}

Insulin-like growth factor-1, is a naturally occurring anti-apoptotic and neurotrophic factor, plays an important role in the regulation of cell proliferation, differentiation and maturation during normal brain development and maturation. Eighty percent of the IGF-1 in serum is bound to IGFBP-3. IGFBP-3 prolongs the half-life and regulates tissue distribution of IGF-1, and regulates the bioavailability of IGF- 1 at the cellular level in target tissues. There is also evidence supporting that the neuroprotective efficacy of IGF-1 is associated with the binding proteins $(17,18,19)$. It is also known to be involved in atherosclerosis development due to its role in cell proliferation. Furthermore, it induces elastin synthesis and prevents apoptosis in vascular smooth muscle cells. Therefore, it constitutes a risk factor for low grade stroke. On the other hand, IGF-1 expression increases in the region with neuronal loss following hypoxic injury, and animal studies using IGF-1 administration have shown shrinkage in infarct volume and improved neurological function following ischemia. This suggests that IGF-1 may have an important role in termination of stroke (12).

Schabitz et al. (20) treated rats with intraventricular and subcutaneous IGF-1 after occluding right carotid artery and found decreased infarct volumes in brain section of the rats in the treated group compared to the untreated group.

Johnsen et al. (21) investigated the association between IGF system and risk of ischemic stroke in a prospective study and found an inverse correlation between IGF-1 and IGFBP-3 levels and risk of stroke in patients with stroke, and suggested that decreased serum levels of IGF1 and IGFBP-3 may be associated with an increased risk of ischemic stroke. In a study (22), serum IGF-1 and IGFBP-3 levels were investigated in patients with acute ischemic stroke at the initial 24 hours, on the day of 3, 5 and 10. Serum IGF-1 levels of the patients were found to be lower compared to the control group at all time points assessed. The lowest IGF-1 value was detected in the large stroke group; however, there was no significant difference across the subgroups. Serum IGFBP-3 levels were significantly lower in the control group on the day of 5 and 10 while the lowest value was detected in the group with large infarct. Across the subgroups, IGFBP-3 levels were significantly lower in the group with large and moderate infarcts on the same days.

Denti et al. (23) compared the IGF-1 and IGFBP-3 levels in patients diagnosed with acute ischemic stroke at the initial 24 hours and at 1 month or discharge, as well as the NIHSS and Barthel indexes at 3 and 6 months, and found significantly lower IGF-1 levels compared to the control group during the acute period while the IGFBP-3 levels were lower without statistical significance. According to the subgroups based on Bamford ischemic stroke scale, there was no significant difference regarding IGF-1; however, the highest IGF-1 level was found in the POCI group and the lowest value was observed in the TACI group. There was no association between the severity of neurological presentation and the IGF-1 and IGFBP-3 levels on the first day. While an inverse correlation was found between the evaluations performed at 1, 3 and 6 months and the IGF-1 levels, and also there was no association between these evaluations and IGFBP-3. Moreover, decreased IGF-1 was found to be associated with increased mortality; however, it was not associated with disability.

IGF-1 and IGFBP-3 levels were not different than the control group at the initial 24 hours in the present study. This finding differs from the findings of Schwab (22) and Denti (23) et al. who found significantly lower serum IGF-1 and IGFBP-3 levels in patients compared to the control group at the end of 24 hours. In our study, we found significantly lower levels of IGFBP-3 compared to the control group only on the day of 5 . This finding supported the decreased IGFBP-3 findings demonstrated by Schwab et al. (22); however, it was not consistent with the decreased IGF-1 levels detected in the same study. While there was no significant association between the IGF-1 and IGFBP-3 levels and the ischemic stroke subgroups based on Bamford scale, lowest IGF-1 levels were detected in the TACI group and exitus occurred within five days in 4 patients with low IGF-1 levels in this group. Showing that the lowest IGF-1 level was found in the large infarct group, our findings support the studies suggesting an association between decreased IGF-1 and increased mortality during the acute period.

Bondanelli et al. (24) investigated the effect of IGF-1 levels on ischemic stroke outcomes in patients in a rehabilitation program following 
acute ischemic stroke, and found no correlation between IGF-1 levels and NIHSS but found a positive correlation between IGF-1 and Functional Independence Measure (FIM) scale used for the assessment of functional status and Rancho Los Amigos Scale (LCFS) used for the assessment of cognitive status. Additionally, patients with high IGF-1 at baseline achieved better outcomes in FIM, MRS and LCFS tests following rehabilitation.

While there was no significant association between NIHSS and IGF-1, IGFBP-3 levels on the first day of the present study, the highest NIHSS scores were found in the TACI group with the lowest IGF-1 levels on the day of 5, supporting the studies by Denti (23) and Bondanelli (24) demonstrating the association with poor prognosis.

In our study, only 27 patients were available for evaluation at the end of one month, and there was no clinically significant association between IGF-1 and IGFBP-3 levels and MRS and NIHSS scores on the day of 30 . Although this finding is not consistent with the findings of Denti et al. (23) demonstrating an association between low IGF-1 levels during the acute period and poor prognosis during the evaluation at the end of one month, it is not considered to be demonstrating our actual results as it does not reflect all of the patients included in the present study.

A review of the current literature has shown that the association between the levels of IGF-1 and IGFBP-3 and the subgroups based on TOAST classification has not been studied yet. Although our study demonstrated no significant association between the subgroups based on TOAST classification and the IGF-1 and IGFBP-3 levels, we believe that these findings may provide an insight for future studies.

Acknowledgment: All the authors indicate that they don't have a financial relationship with the organization that sponsored the research

\section{REFERENCES}

1. Nedeltchev K, der Maur TA, Georgiadis D, et al. Ischaemic stroke in young adults: predictors of outcome and recurrence. J Neurol Neurosurg Psychiatry 2005;76:191195.

2. Frystyk J, Ledet $\mathrm{T}$, Moller $\mathrm{N}$, Flyvbjerg A, Orskov $\mathrm{H}$. Cardiovascular disease and insulin-like growth factor I. Circulation 2002;106:893-895

3. Van Bunderen CC, van Nieuwpoort IC, van Schoor NM, et al. The association of serum insulin-like growth factor-I with mortality, cardiovascular disease, and cancer in the elderly: a population-based study. J Clin Endocrinol Metab 2010; 95: 4616-4624.

4. Godau J, Herfurth M, Kattner B, Gasser T, Berg D. Increased serum insulin-like growth factor 1 in early idiopathic Parkinson's disease. J Neurol Neurosurg Psychiatry 2010; 81: 536-538.

5. Bayes-Genis A, Conover CA, Schwartz RS. The Insulin-Like Growth Factor Axis. A Review of Atherosclerosis and Restenosis. Circulation Research 2000; 86:125-130.

6. Benarroch EE. Insulin-like growth factors in the brain and their potential clinical implications. Neurology 2012; 79: 2148-2153.

7. Chesik D, De KJ, Wilczak N. Insulin-like growth factor system regulates oligodendroglial cell behavior: therapeutic potential in CNS. J Mol Neurosci 2008;35: 8190.

8. Strbian D, Durukan A, Pitkonen M, et al. The blood-brain barrier is continuously open for several weeks following transient focal cerebral ischemia. Neuroscience 2008; 153:175-181.

9. Johnsen SP, Hundborg HH, Sorensen HT, et al. Insulin-like growth factor (IGF) I, II, and IGF binding protein-3 and risk of ischemic stroke. J Clin Endocrinol Metab 2005; 90:59375941.

10. Laughlin GA, Barrett-Connor E, Criqui MH, Kritz-Silverstein D. The prospective association of serum insulin-like growth factor I (IGF-I) and IGF binding protein-1 levels with all cause and cardiovascular disease mortality in older adults: the Rancho Bernardo Study. J Clin Endocrinol Metab 2004;89:114-120.

11. Selvamani A, Sohrabji F. The neurotoxic effects of estrogen on ischemic stroke in older female rats is associated with age-dependent loss of insulin-like growth factor-1. J Neurosci 2010;30: 6852-6861.

12. Van Rijn MJ, Slooter AJ, Bos MJ, et al. Insulin-like growth factor I promoter polymorphism, risk of stroke, and survival after stroke: the Rotterdam study. J Neurol Neurosurg Psychiatry 2006;77:24-27.

13. Bamford J, Sandercock P, Dennis M, Burn J, Warlow CP. Classification and Naturel History of Clinically Identifiable Subtypes of Serebral Infarction. The Lancet 1991; 337:1521-1526.

14. Adams HP, Bendixen BH, Kappelle LJ. Classification of Subtype of Acute Ischemic Stroke. Stroke 1993;24:35-41.

15. The National Institute of Neurologcal Disorders and Stroke rt-PA Stroke Study Grup: Tissue Plasminogen Activator for Akut Ischemic Stroke. N Engl J Med 1995; 335:1581-1587.

16. Van Swieten JC, Koudstaal PJ, Visser MC, Schouten HJ, van Gijin J. Interobserver Agreement for The Assessment of Handicap in Stroke Patients. Stroke 1988;19:604-607.

17. Kooijman R. Regulation of Apopitosis by İnsulin-Like Growth Factor (IGF)-1. Cytokine\&Growth Factor Reviews 2006;17:305-323.

18. Guan J, Bennet L, Gluckman PD, Gunn AJ. İnsulin-Like Growth Factor and Post-İschemic Brain İnjury. Progress in Neurobiology 2003;70:443-462.

19. Eva Carro, Inacio Torres-Aleman. Serum İnsulin-Like Growth Factor 1 in Brain Function. Keijo J Med 2006; 55: 59-63.

20. Schabitz WR, Hoffmann TT, Heiland S, et al. Delayed Neuroprotective Effect of Insulin-Like Growth Factor-1 After Exprimental Transient Focal Cerebral Ischemia Monitored With MRI. Stroke 2001;32:1226-1233.

21. Johnsen SP, Hundborg HH, Sorensen HT, et al. Insulin-Like Growth Factor (IGF)-1, -2, and IGF Binding Protein-3 and 
Yasar et al

Risk of Ischemic Stroke. The journal of Clinical Endocrinology\&Metabolizm 2005;90:5937-5941.

22. Schwab S, Spranger M, Krempien S, Hacke W, Bettendorf M. Plasma Insulin-Like Growth Factor 1 and IGF Binding Protein 3 Levels in Patient With Acute Cerebral Ischemic Injury. Stroke 1997;28:1744-1748.
23. Denti L, Annoni V, Cattadory E, et al. İnsulin-Like Growth Factor 1 as a Predictor of İschemic Stroke Outcome İn the Elderly. Am J Med.2004;117: 12-317.

24. Bondalelli M, Ambrosio MR, Onofri A, et al. Predictive Value of Circulating İnsulin-Like Growth Factor 1 Levels in Ischemic Stroke Outcome. The Journal of Clinical Endocrinology\&Metabolism 2006;91:3928-3934. 